\title{
TINJAUAN PERTANGGUNGJAWABAN PIDANA WAJIB PAJAK BADAN DALAM TINDAK PIDANA DI BIDANG PERPAJAKAN
}

\author{
Wan Juli \\ Titik Suharti \\ PSS Consult - Ernst and Young Surabaya \\ e-mail:wan.juli73@yahoo.com
}

\begin{abstract}
ABSTRAK
Dalam penulisan ini, kami menelaah secara kritis dasar yuridis dari cakupan pidana dalam Undang-Undang No. 6 Tahun 1983 sebagaimana telah diubah terakhir dengan Undang-Undang No. 16 Tahun 2009 tentang Ketentuan Umum dan Tata Cara Perpajakan (UU KUP) yang berfokus pada pertanggungjawaban pidana korporasi dan sanksi pidana yang terkait dengan pelanggaran tindak pidana di bidang perpajakan. penulisan ini bermula dengan pemaparan mengenai pertanggungjawaban pidana pada korporasi sebagai suatu prasyarat pemidanaan korporasi. Kami menganalisis tindak pidana di bidang perpajakan yang diatur dalam UU KUP dalam hal subjek hukum yang dicakup oleh UU KUP dan sanksi pidana dalam hal terjadi pelanggaran tindak pidana tersebut. Kami menyimpulkan adanya ketidakkonsistenan dalam pertanggungjawaban pidana terhadap korporasi dan sanksi pidananya yang diatur dalam Pasal 38, 39, dan 39A UU KUP. Kami akhirnya memberikan beberapa saran untuk perbaikan undang-undang ini dalam aspek pertanggungjawaban pidana untuk korporasi dan sanksi pidananya.

Kata Kunci: kejahatan korporasi, inkonsistensi, pertanggungjawaban pidana.

\section{ABSTRACT}

In this legal research, will be critically examined the legal basis of the criminal coverage in the General Provision of Taxes Law (UU KUP) (Law No. 6/1983 which amended by Law No. 16/2009), which focused on the corporate criminal responsibility, and the criminal sanction related to tax crime. Started from the description of corporate criminal responsibility as a prequisite of corporate criminal penalty, then will be examined about the tax crime which regulated in UU KUP, especially about the criminal subject and the penalty. It is concluded that there are some inconsistencies about the corporate criminal responsibility and also the penalty which is regulated in Article 38, 39 and 39A UU KUP.
\end{abstract}

Keywords: corporate crime, inconsistencies, criminal responsibility.

\section{PENDAHULUAN}

Penjelasan Pasal 38 yang mengawali Bab VIII Ketentuan Pidana menyebutkan bahwa pelanggaran terhadap suatu kewajiban perpajakan yang dilakukan oleh wajib pajak, sepanjang menyangkut tindakan administrasi perpajakan, dikenai sanksi administrasi dengan menerbitkan suatu Surat Ketetapan Pajak atau Surat Tagihan Pajak, sedangkan yang menyangkut tindak pidana di bidang perpajakan dikenai sanksi pidana. Dengan demikian, yang diancam dengan sanksi pidana adalah perbuatan atau tindakan yang bukan merupakan pelanggaran administrasi melainkan merupakan tindak pidana di bidang perpajakan.

Apabila dicermati lebih lanjut, delik di bidang perpajakan yang tampaknya dapat dilakukan oleh wajib pajak badan diatur dalam Undang-Undang No. 16 Tahun 2009 tentang Ketentuan Umum dan Tatacara Perpajakan (yang selanjutnya akan disebut UU KUP) dalam Pasal 38, 39, dan 39A. Apabila Pasal 38 terkait dengan kelalaian atau kealpaan yang terkait dengan penyampaian Surat Pemberitahuan Tahunan (SPT), maka Pasal 39 berfokus pada kesengajaan sebagai alasan pemidanaan yang terkait dengan pelaksanaan kewajiban di bidang perpajakan. Di lain pihak Pasal 39A merupakan pengaturan delik pidana di bidang perpajakan terkait dengan kesengajaan penerbitan atau penggunaan faktur pajak, yang khusus untuk jenis pajak PPN. Namun demikian, cukup menarik untuk disimak bahwa rumusan yang digunakan dalam 
pasal-pasal ini menggunakan istilah setiap orang yang secara harafiah berarti individu dan tidak termasuk wajib pajak badan. Tulisan ini membahas mengenai pertanggungjawaban wajib pajak badan dalam tidak pidana di bidang perpajakan, sanksi pidana yang dapat dikenakan kepada wajib pajak badan ini, dan beberapa hal yang dapat menimbulkan kontroversi dalam praktik perpajakannya. Pertama-tama, konsep pertanggungjawaban pidana akan dibahas secara ekstensif diikuti dengan tindak pidana di bidang perpajakan yang dapat dilakukan oleh wajib pajak badan beserta dengan sanksi-sanksi pidananya. Bagian terakhir dari tulisan ini akan membahas mengenai beberapa aspek inkonsistensi beserta dengan arah perkembangan ke depan dari rumusan delik pajak dalam UU KUP.

\section{PEMBAHASAN}

\section{Pertanggungjawaban Pidana bagi Wajib Pajak Badan: Tinjauan Hukum Pidana}

UU KUP tersebut juga tidak banyak membahas mengenai pertanggungjawaban pidana bagi wajib pajak sekalipun hal ini cukup penting untuk dapat disebutkan karena pertanggungjawaban ini memiliki implikasi terhadap siapa saja yang dapat di pidana dan faktor apa yang mendasari pemidanaan itu dan apabila memang ada pihak-pihak tertentu yang dapat dikenai sanksi pidana, maka pertanggungjawaban pidana ini ternyata juga berakibat pada siapa yang memiliki tanggungjawab untuk membuktikannya. Tanggungjawab dalam pembuktian ini tentu saja paling relevan dalam hal hukum acara pidana yang bermula dari penyelidikan, penyidikan, penuntutan dan persidangan. Namun demikian, dalam konteks hukum pidana, secara teoritis dikenal 3 (tiga) konsep umum dalam hal pertanggungjawaban pidana yaitu: Pidana tanpa kesalahan; Strict liability; dan Vicarious liability.

\section{Pidana Tanpa Kesalahan}

Konsep pidana tanpa kesalahan ini adalah konsep yang secara tradisional dianut dalam Kitab UndangUndang Hukum Pidana (selanjutnya disebut KUHP) yang berlaku di Indonesia dengan Undang-Undang No. 8 Tahun 1981. Dalam konsep ini, yang dapat dipertanggungjawabkan secara pidana adalah hanya individu dan atau orang pribadi, sedangkan Badan tidak dapat dipertanggungjawabkan secara pidana. Rumusan asas ini adalah actus non facit reum nisi mens sit rea yang terjemahannya adalah bahwa suatu perbuatan tidak dapat menjadikan seseorang bersalah bilamana maksudnya tidak bersalah (Farid, 2007:42).
Dalam konteks ini, sama sekali tidak dapat diartikan bahwa delik yang dilakukan oleh suatu korporasi sama sekali tidak terancam sanksi pidana, tetapi ide dasar dari konsep ini adalah bahwa pengurus korporasi itulah yang dianggap bertanggungjawab. Muladi dan Priyatno mengemukakan untuk diperhatikan bahwa dalam konteks ini, dua model alternatif pemidanaan terhadap korporasi adalah bahwa pengurus korporasi sebagai pembuat dan penguruslah yang bertanggung jawab dan/atau bahwa korporasi sebagai pembuat dan pengurus bertanggung jawab (Muladi dan Priyatno, 2010:217).

Karena itu, dalam konsep di atas, yang dipidana adalah pengurus dari korporasi itu. Hal ini juga sejalan dengan kriteria tentang korporasi sebagai pelaku delik berdasarkan konsep delik fungsional. Maksud dari delik fungsional ini adalah bahwa badan hukum dapat diperlakukan sebagai pelaku delik dari perbuatan yang melawan hukum yang pertanggungjawabannya dapat dibebankan atas badan hukum, dilakukan dalam rangka pelaksanaan tugas dan/atau pencapaian tujuan korporasi itu (Muladi dan Priyatno, 2010:221).

Pada intinya, sebelum pemidanaan, asas tiada tanpa kesalahan ini mensyaratkan adanya perbuatan pidana yang secara umum dan objektif dapat diatur di dalam suatu undang-undang (KUHP) dan undangundang lain yang secara khusus mengatur tentang ketentuan pidana. Perbuatan pidana tidak sematamata melakukan perbuatan (aktif) tetapi bertentangan dengan kaidah hukum pajak. Disamping perbuatan dalam arti aktif ini, unsur perbuatan lain adalah tidak melakukan perbuatan (pasif), namun hal ini memenuhi rumusan kaidah hukum pajak sehingga termasuk delik pajak (Saidi dan Djafar, 2011:3).

Setelah pertimbangan unsur fisik itu, hakim akan mempertimbangkan apakah hal yang bersangkutan bersalah sebelum menjatuhkan sanksi pidana. Faktor kedua ini adalah faktor dari dalam pembuat delik (pelaku) itu sendiri (pertanggungjawaban pidana). Pertanggungjawaban pidana atau mens rea mencakup unsur-unsur sikap batin pelaku, yang salahsatunya mencakup kesalahan dalam arti yang luas. Kesalahan dalam arti luas ini meliputi kesengajaan dan kelalaian (kealphaan). Unsur kealphaan disini memiliki makna bahwa terdakwa tidak mengadakan penduga-duga yang perlu menurut hukum atau tidak mengadakan penghati-hati atau due care sebagaimana diharuskan oleh hukum (Moeljatno, 2008:217). Secara sederhana, dalam kealphaan ini tidak mengenal adanya keinginan ataupun pengetahuan atau dengan kata lain, kealphaan terjadi apabila tidak terbukti adanya kesengajaan. Secara teori, kesengajaan ini dapat bermakna bahwa 
wajib pajak mengetahui akan delik yang dilakukan beserta dengan akibat-akibat hukumnya dan dapat pula berarti bahwa wajib pajak memiliki keinginan untuk melakukan suatu delik tertentu, misalnya untuk memperoleh pengembalian pajak atau restitusi dengan menggunakan tanpa Hak Pengukuhan Pengusaha Kena Pajak, atau pun untuk mengecilkan jumlah pajak terutang dengan membuat pembukuan yang tidak sesuai dengan kenyataannya.

Moeljatno menyatakan bahwa teori pengetahuan lebih memadai daripada teori kehendak karena dalam kehendak itu sudah tercermin adanya pengetahuan. Dalam praktik adalah sulit untuk menilai pengetahuan terdakwa dalam delik perpajakan. Namun demikian, bahwa latar belakang pendidikan terdakwa dapat mengarahkan seorang hakim untuk dapat berasumsi mengenai pengetahuan terdakwa. Dengan kata lain pengetahuan yang seharusnya lebih luas cakupannya daripada kehendak (Moeljatno, 2008:187).

Konsekuensinya adalah bahwa dalam pembuktian mengenai kehendak diperlukan pengujian atas dua aspek, yaitu: Perbuatan itu sesuai dengan motif untuk berbuat dan tujuan yang hendak dicapai; dan Antara motif, perbuatan, dan tujuan harus ada hubungan kausal dalam batin terdakwa.

Sistem hukum Eropa Kontinental yang dalam banyak hal dianut oleh Indonesia membedakan atas 3 (tiga) corak kesengajaan, yaitu: Sengaja sebagai maksud atau opzet als oogmerk; Sengaja sadar atau insaf akan keharusan dan atau sadar akan kepastian (opzet bij noodzakelijkheidsbewustzijn dan atau bij zekerheidsbewustzijn). Utrecht menguraikan dan menterjemahkan sebagai sengaja dilakukan dengan keinsyafan bahwa, agar suatu tujuan dapat tercapai, sebelumnya harus dilakukan suatu perbuatan lain yang berupa pelanggaran atau delik pula; Sengaja sadar akan kemungkinan (opzet bij mogelijkheidsbewustzijn atau dolus eventualis) (Farid, 2007:235).

Sengaja sebagai maksud mensyaratkan adanya hubungan antara perbuatan dengan kehendak atau volition terdakwa. Banyak orang yang mengartikan sengaja sama dengan niat atau maksud saja, sekalipun hal ini hanya merupakan salah satu unsur umum dalam kesengajaan. Selain adanya maksud, corak kesengajaan juga meliputi kepastian atau keharusan dan kemungkinan yang mengacu pada hubungan antara pikiran atau intelek pelaku dengan perbuatan yang dilakukan. Dalam sadar akan suatu kepastian, terkandung makna bahwa akibat dan atau keadaan yang menyertai diketahui betul akan ada (terjadi) terlepas dari akibat ini dikehendaki atau yang tidak dikehendaki.

\section{Strict Liabilility Concept}

Berbeda dengan konsep sebelumnya yaitu Tiada Pidana Tanpa Kesalahan, konsep ini pada intinya tidak mensyaratkan adanya kesalahan dalam setiap delik sebagai prasyarat atau unsur pemidanaan. Hal ini dapat dipandang sebagai pengembangan dari konsep sebelumnya mengingat hakikat korporasi sebagai abstraksi tanpa pikiran sendiri yang mana kehendak yang dijalankan dan bersifat mengarahkan harus dilihat pada seseorang atau pejabat seniornya dengan kedudukan dan kekuasannya untuk berperan sebagai otak korporasi (Adhyaksana, 2008:xxvii). Pejabat senior disini secara hukum maksudnya adalah orangorang yang mengendalikan korporasi, baik sendirian maupun bersama-sama dengan pejabat yang lain yang bertindak untuk dan atas nama korporasi.

Dengan demikian, jelas dikatakan bahwa suatu pertanggungjawaban pidana untuk korporasi tidak dapat diinterpretasikan bahwa korporasilah yang melakukan delik, melainkan para pejabat dan orangorang yang bekerja untuk dan atas nama korporasi itu. Korporasi dalam delik perpajakan maksudnya adalah badan yang didefinisikan dalam UU KUP yaitu sebagai sekumpulan orang dan/atau modal yang merupakan kesatuan baik yang melakukan usaha maupun yang tidak melakukan usaha yang meliputi perseroan terbatas, perseroan komanditer, perseroan lainnya, badan usaha milik negara atau badan usaha milik daerah dengan nama dan dalam bentuk apa pun, firma, kongsi, koperasi, dana pensiun, persekutuan, perkumpulan, yayasan, organisasi massa, organisasi sosial politik, atau organisasi lainnya, lembaga dan bentuk badan lainnya termasuk kontrak investasi kolektif dan bentuk usaha tetap.

Pemidanaan korporasi dalam konsep strict liability ini tampaknya diciptakan untuk mengatasi kesulitankesulitan yang dialami oleh penuntut umum dalam membuktikan adanya intensi, keinginan, pengetahuan, kesembronoan, atau pun keacuhan atau negligence. Dengan dieliminasinya unsur-unsur kesalahan ini, pertanggungjawaban pidana dipandang ada apabila suatu delik dilakukan. Suatu indikasi dari penerapan konsep ini dalam undang-undang misalnya adalah dengan dihilangkannya kata-kata seperti: dengan pengetahuannya, dengan maksud atau tujuannya, dengan itikad buruk, yang menunjukkan bahwa unsur kesalahan adalah elemen yang diperlukan.

Beberapa faktor berikut ini dipandang sangat penting dalam menentukan bahwa suatu undangundang dimaksudkan untuk menganut suatu konsep pidana tanpa kesalahan atau liability without fault atau sebaliknya, mensyaratkan adanya kesalahan 
sekalipun adanya unsur kesalahan ini tidak dinyatakan dengan jelas (LaFave and Scott, 1986:244): Sejarah pembentukan perundang-undangan yang bersangkutan atau judul maupun konteksnya menunjukkan adanya pengadopsian konsep ini; Adanya peraturan lain yang memberikan suatu panduan kepada hakim untuk menentukan bilamana strict liability harus diterapkan; Beratnya pemidanaan untuk delik itu sangat penting; Keseriusan dampak delik-delik itu terhadap publik. Semakin serius suatu delik terhadap publik, semakin menunjukkan perlunya konsep liability without fault ini. Paling tidak, keseriusan dampak delik terhadap publik ini dijadikan pertimbangan dalam undangundang khusus yang mengatur delik tertentu, misalnya delik korupsi; Kemampuan penuntut umum dalam menemukan fakta yang valid juga merupakan faktor penentu penerapan konsep ini. Apabila semakin sulit bagi penuntut umum untuk membuktikan kebenaran tuntutannya, semakin mungkin penerapan konsep ini; Tingkat kesulitan penyidik dalam membuktikan sikap batin pelaku. Semakin sulit pembuktian sikap batin ini, semakin mungkin penerapan konsep ini; Jumlah penuntutan (kasus yang dibawa ke pengadilan) yang diharapkan adalah faktor penting lain. Semakin sedikit jumlah kasus ini kemungkinan mensyaratkan penuntut umum untuk melakukan pemeriksaan dan penyidikan mengenai unsur kesalahan ini.

Dalam praktik, konsep ini bisa juga memiliki variasi lain yang tetap mengharuskan adanya unsurunsur kesalahan atau fault, namun dengan pembuktian adanya kesalahan ini tidak diletakkan sebagai beban penuntut umum, melainkan pada pihak terdakwa (pembuktian terbalik). Secara konstitusional, di dalam konteks yang ada di undang-undang dapat merupakan suatu indikasi penerapan konsep ini, yaitu misalnya adanya penggolongan delik sebagai kejahatan yang pemberantasannya harus dilakukan secara luar biasa seperti yang dinyatakan di dalam Undang-Undang No. 20 Tahun 2001 tentang Perubahan atas UndangUndang No. 31 Tahun 1999 tentang Pemberantasan Tindak Pidana Korupsi.

Hal ini rupanya untuk mengantisipasi beberapa pendapat yang menyatakan bahwa penerapan konsep strict liability ini tidak konstitusional apabila (LaFave and Scott, 1986:247): Perihal dalam undang-undang itu tidak menyebutkan bahwa suatu delik tergolong sebagai pelanggaran kesejahteraan publik atau public welfare offences; Undang-undang itu membawa sanksi pidana yang substansial; dan Undang-undang itu mengenakan kewajiban dalam hal tanggungjawab seseorang untuk meyakinkan atau membuktikan fakta yang relevan.

\section{Vicarious Liability Concept}

Dalam konsep seperti ini, pihak terdakwa, pada umumnya memiliki dan menjalankan suatu usaha tertentu, dan berkewajiban untuk bertanggungjawab, sekalipun tanpa adanya unsur kesalahan personal seperti konsep tiada pidana tanpa kesalahan, untuk perbuatan melanggar hukum yang dilakukan oleh orang lain yang pada umumnya adalah karyawannya sendiri. Dalam praktik ada kecenderungan bahwa perbedaan antara strict liability dan vicarious liability ini tidak diperhatikan, sekalipun keduanya memiliki perbedaan yang penting. Dengan strict liability, unsur pokoknya adalah adanya delik yang dilakukan oleh terdakwa sekalipun konsep ini tidak memerlukan elemen kesalahan atau mental fault.

Sebaliknya dalam konsep vicarious liability, unsur perbuatan atau delik yang dilakukan oleh terdakwa ini diabaikan dalam arti tidak diperlukan, tetapi konsep ini memerlukan pentingnya elemen kesalahan di pihak karyawan terdakwa. Kedua konsep ini, strict liability dan vicarious liability ini tidak perlu terpisah dalam artian bahwa dalam beberapa jurisdiksi adalah umum terjadi penerapan vicarious liability dibarengi dengan strict liability. Dalam kasus ini, pembuktian mengenai adanya delik yang dilakukan oleh perusahaan tidak relevan dan pembuktian mengenai adanya kesalahan tidak diperlukan. Dalam praktik perundang-undangan, penerapan di konsep ini dapat diindikasikan lewat beberapa frasa, misalnya "siapa saja, melakukan sendiri atau melalui agennya ...." dan juga "perbuatan oleh karyawan dapat dipandang sebagai perbuatan dari perusahaan maupun karyawannya".

Kedua konsep terakhir ini, baik strict liability maupun vicarious liability, memang tidak dicakup dalam KUHP, namun konsep KUHP 1993 maupun Konsep 2004-2005 sudah mengadopsi kedua konsep ini (Arief, 2010:85-86). Pada Pasal 37 ayat 2 Konsep 2005 menyebutkan, bahwa bagi suatu tindak pidana tertentu undang-undang dapat menentukan bahwa seseorang dapat dipidana semata-mata karena telah dipenuhinya unsur-unsur tindak pidana tersebut tanpa memperhatikan adanya kesalahan. Hal ini jelas sekali menunjukkan pengadopsian konsep strict liability.

Di lain pihak, Pasal 37 ayat 3 Konsep 2005, yang menyatakan bahwa dalam hal tertentu, setiap orang dapat dipertanggungjawabkan atas tindak pidana yang dilakukan oleh orang lain, jika ditentukan dalam suatu undang-undang, jelas menunjukkan penerapan konsep vicarious liability. Yang menjadi permasalahan dalam praktik adalah apakah perusahaan dapat dipandang yang bertanggungjawab atas perbuatan karyawannya sekalipun di perusahaan itu tidak mengetahui atau 
bahkan tidak memberikan suatu wewenang kepada karyawannya untuk melakukan suatu delik. Hal ini tidak terlalu jelas dalam beberapa beberapa jurisdiksi. Namun demikian, secara normatif, delik yang diancam dengan penerapan konsep ini harus bersifat kejahatan atau crime (bukan pelanggaran) dan sanksi pidana bagi pengusaha tidak lebih dari pidana denda atau sanksi sipil lainnya (tidak boleh pidana penjara).

Variasi lain dari suatu konsep pertanggungjawaban pidana tanpa kesalahan atau liability without fault adalah enterprise liability yang pada intinya atau pokoknya menunjukkan bahwa suatu korporasi dapat dipertanggungjawabkan secara pidana untuk delik yang dilakukan oleh agennya yang bertindak atas nama korporasi itu dalam lingkup pekerjaannya atau employment. Dalam pandangan lain yang diistilahkan dengan superior agent rule, pertanggungjawaban pidana atas korporasi hanya diterapkan untuk delik yang dilakukan oleh direktur atau agen dengan posisi sebagai manajerial puncak. Karyawan perusahaan pada umumnya tidak dapat dipertanggungjawabkan secara pidana untuk perbuatan yang dilakukan oleh korporasi atau bawahannya, kecuali dalam prinsip pertanggungjawaban.

Suatu prinsip accountability ini secara sederhana, maksudnya adalah adanya suatu wewenang untuk melakukan suatu tindakan tertentu. Jika seseorang terlibat dalam tindak pidana atau diarahkan atau diijinkan untuk melakukan delik itu, maka sudah jelas bahwa kejahatan ini dilakukan untuk dan atas nama korporasi. Dalam hal ini, korporasi ini dapat dipertanggungjawabkan secara pidana untuk delik yang dilakukan oleh karyawannya yang bertindak untuk dan atas nama korporasi itu. Jika suatu korporasi dapat dikenai suatu sanksi pidana terhadap delik yang dilakukan oleh agen atau karyawannya, maka hal ini jelas menunjukkan penerapan konsep vicarious liability. Yang perlu diperhatikan sehubungan dengan konsep ini adalah bahwa pertanggungjawaban pidana untuk korporasi ini tidak dapat diterapkan untuk semua delik. Dalam praktik, seringkali implikasi dari konsep ini adalah adanya pidana denda yang dijatuhkan terhadap suatu korporasi.

Dalam perkembangan yang ada bahkan pemegang saham pun juga dapat dipertanggungjawabkan secara pidana terhadap delik yang dilakukan oleh manajemen korporasi atau pun karyawan korporasi itu. Hal ini diistilahkan dengan vicarious liability twice removed. Terlepas dari variasi dalam penerapannya, konsep umum yang harus dipegang teguh adalah bahwa pertanggungjawaban pidana atas korporasi ini hanya diterapkan untuk delik yang dilakukan oleh agen atau karyawan korporasi itu yang bertindak untuk dan atas nama korporasi yang bersangkutan dalam lingkup hubungan kerja atau employment. Namun demikian, hal ini tidak berarti bahwa korporasi itu dapat lepas tanggungjawab dengan berargumen bahwa perbuatan pidana itu di luar kuasa dari korporasi yang bersangkutan atau ultra vires, bahwa karyawan yang bersangkutan tidak diberi wewenang spesifik, atau bahwa agen itu bertindak tidak sesuai dengan instruksi yang diberikan. Sebaliknya, delik pidana ini berhubungan langsung dengan pelaksanaan tugas yang mana agen atau karyawan yang bersangkutan memiliki suatu kewenangan yang cukup besar untuk dapat melaksanakannya dan harus dilakukan dengan sengaja.

\section{Rumusan Delik Pidana yang Dapat Dilakukan oleh Wajib Pajak Badan dalam UU KUP}

Di dalam UU KUP, suatu tindak pidana di bidang perpajakan yang dapat dilakukan oleh Wajib Pajak di atur dalam rumusan delik yang dijabarkan dalam Pasal 38, 39 ayat 1, 2, 3, dan 39A. Pasal 38 mengatur tentang kealpaan atau kelalaian, sementara Pasal 39 dan 39A mengatur tentang kesengajaan. Pasal 38 ini pada intinya mengatur delik yang dilakukan karena kealphaan dan terbatas pada SPT yang tidak disampaikan atau disampaikan tidak lengkap atau tidak benar. Kealpaan dalam penjelasan pasal ini diartikan dengan tidak sengaja, lalai, tidak hati-hati, atau kurang mengindahkan kewajibannya sehingga perbuatan tersebut dapat menimbulkan kerugian pada pendapatan negara. Beberapa unsur penting dalam Pasal 38 ini adalah: Delik itu dilakukan oleh orang; Karena kealphaannya; Menimbulkan kerugian pada pendapatan negara; dan Perbuatan itu bukan perbuatan pertama atau perbuatan ulangan.

Berdasar pasal ini ancaman pidananya adalah denda paling sedikit 1 (satu) kali jumlah pajak terutang yang tidak atau kurang dibayar dan paling banyak 2 (dua) kali jumlah pajak terutang yang tidak atau kurang dibayar. Pidana alternatifnya adalah pidana kurungan paling singkat 3 (tiga) bulan atau paling lama 1 (satu) tahun.

Lebih lanjut lagi, Pasal 39 ayat 1 dan 39A mengatur delik yang dilakukan dengan unsur kesengajaan. Pada Pasal 39 ayat 1 tampaknya lebih berfokus pada orang yang melalaikan kewajiban perpajakannya, sehingga unsur penting dalam delik ini adalah: Delik itu dilakukan oleh orang; Karena dengan kesengajaan; Menimbulkan kerugian pada pendapatan Negara.

Di lain pihak, Pasal 39A adalah delik kesengajaan yang berfokus pada kewajiban wajib pajak sebagai 
pemotong atau pemungut pajak (terkait dengan PPN dan PPh Pemotongan atau Pemungutan). Selain itu, delik sebagaimana di atur dalam Pasal 39A ini tidak mensyaratkan adanya pembuktian kerugian pada pendapatan Negara. Sejalan dengan rumusan Pasal 39 ayat 1 , ini pada ayat 2 pasal ini tampaknya lebih mengarah kepada pengulangan delik atau recidive yang juga diancan dengan sanksi pidana. Di lain pihak, Pasal 39 ayat 3 dimaksudkan untuk mengatur tentang delik percobaan yang terbatas pada suatu tindakan menyalahgunakan atau menggunakan tanpa hak NPWP dan/atau NPPKP.

\section{Pertanggungjawaban Wajib Pajak Badan}

Sebelum memulai tentang pembahasan mengenai pertanggungjawaban wajib pajak badan dan korporasi dalam tindak pidana di bidang perpajakan, hal pokok yang perlu dipahami adalah apakah rumusan delik pidana di dalam UU KUP memang secara implisit mencakup wajib pajak badan, mengingat rumusan delik dalam UU KUP menggunakan istilah setiap orang. Setelah itu, aspek kedua yang perlu dianalisis lebih lanjut adalah suatu konsep pertanggungjawaban pidana apakah yang digunakan dalam rumusan delik UU KUP. Apabila wajib pajak badan ini memang termasuk di dalam subjek pajak yang dapat dapat dipertanggungjawabkan secara hukum pidana, maka aspek terakhir yang perlu dikaji adalah mengenai sanksi apakah yang dapat dikenakan pada wajib pajak badan tersebut.

Sebelum mempertimbangkan mengenai aspek pertanggungjawaban pidana adalah penting untuk mengkaji lebih lanjut, apakah wajib pajak badan (korporasi) dapat menjadi subjek hukum untuk delik yang berhubungan dengan perpajakan sebagaimana disebut dalam UU KUP ini. Hal ini penting untuk dicermati mengingat istilah yang digunakan dalam perumusan delik adalah setiap orang yang makna sempitnya adalah orang perorang atau individu dan bukan korporasi atau wajib pajak badan. Beberapa unsur pendukung yang dapat mengarahkan wajib pajak badan sebagai subjek hukum dalam konteks delik Pasal 38, 39, dan 39A ini adalah sebagai berikut:

Pertama, penjelasan Pasal 38 bahwa pelanggaran terhadap kewajiban perpajakan yang telah dilakukan oleh wajib pajak, sepanjang menyangkut tindakan administrasi perpajakan, dikenai sanksi administrasi dengan menerbitkan Surat Ketetapan Pajak atau Surat Tagihan Pajak, sedangkan yang menyangkut tindak pidana di bidang perpajakan dikenai sanksi pidana. Dengan demikian, pada penjelasan pasal ini ternyata tidak menggunakan istilah setiap orang melainkan wajib pajak yang maknanya sangat luas yaitu meliputi wajib pajak orang pribadi dan wajib pajak badan. Apabila penjelasan ini diartikan sebagai interpretasi pembuat undang-undang, maka jelas sekali bahwa yang dimaksud dengan setiap orang disini maksudnya adalah wajib pajak yang berarti bisa wajib pajak badan atau wajib pajak orang pribadi.

Kedua, secara logika, delik pajak sebagaimana dirumuskan di dalam UU KUP ini tentu saja dapat dilakukan oleh wajib pajak badan sebagai pemegang hak dan kewajiban di bidang perpajakan. Karena itu, adalah tidak masuk akal apabila rumusan delik itu diinterpretasikan bahwa hanya wajib pajak orang pribadi saja yang dicakup dalam rumusan delik itu.

Ketiga, istilah orang dalam rumusan delik ini dapat dipadankan dengan person (bahasa Inggris) dan istilah person tidak selalu berarti individu melainkan juga korporasi, kecuali adanya intensi dari suatu undangundang atau peraturan untuk membatasi istilah orang sebagai hanya mencakup individu. Terkait dengan hal ini, Pasal 1 UU KUP sama sekali tidak memberikan definisi tentang orang. Istilah person dalam konteks hukum pidana yang dianut di negara-negara dengan sistem Common Law memiliki makna person in law yang mencakup juga korporasi atau badan hukum (LaFave and Scott, 1986:258).

Keempat, ketiadaan istilah wajib pajak dalam penjelasan Pasal 39 dan 39A, seperti yang dirumuskan dalam Pasal 38, tidak dapat diartikan bahwa delik ini tidak mencakup wajib pajak badan. Makna istilah setiap orang yang mencakup korporasi atau wajib pajak badan ini juga tercermin dari rumusan pada pasal 43 yang menyebutkan bahwa ketentuan pada Pasal 39 dan Pasal 39A, berlaku juga bagi wakil, kuasa, pegawai dari wajib pajak, atau pihak lain yang menyuruh melakukan, yang turut serta melakukan, yang menganjurkan, atau yang membantu melakukan delik itu. Apabila delik yang dirumuskan dalam Pasal 39 dan 39A ini disebut berlaku juga bagi pegawai dari wajib pajak, maka dapat disimpulkan bahwa delik sebagaimana diatur dalam Pasal 39 dan 39A itu memang ditujukan kepada wajib pajak secara umum yang meliputi wajib pajak badan dan wajib pajak orang pribadi. Hal ini juga dapat diidentifikasikan dari penjelasan Pasal 43 ini yang menyebutkan bahwa yang dapat dipidana karena melakukan delik ini tidak terbatas pada wajib pajak, wakil wajib pajak, kuasa wajib pajak, pegawai wajib pajak, akuntan publik, konsultan pajak, atau pihak lain, tetapi juga terhadap mereka yang menyuruh melakukan, yang turut serta melakukan, yang menganjurkan, atau yang membantu melakukan tindak pidana di bidang perpajakan. 
Dengan demikian, jelas bahwa istilah setiap orang yang digunakan dalam rumusan delik Pasal 38, 39, dan 39A ini memiliki makna yang luas yaitu wajib pajak, karena merekalah yang mengemban hak dan kewajiban menurut hukum pajak.

\section{Konsep Pertanggungjawaban Pidana}

Apabila dicermati dari rumusan delik, jelas sekali bahwa konsep pertanggungjawaban yang digunakan dalam delik pajak ini adalah suatu konsep tradisional yaitu Tiada Pidana Tanpa Kesalahan. Hal ini dapat disimpulkan dari cakupan unsur kesengajaan dalam rumusan pada Pasal 39 dan 39A dan kelalaian dalam rumusan Pasal 38. Dengan demikian, jelas sekali bahwa konsep strict liability tidak diterapkan dalam delik di bidang perpajakan dalam konteks UU KUP ini. Yang perlu dikaji lebih lanjut adalah apakah delik ini mencerminkan adanya penggunaan konsep vicarious liability.

Apakah rumusan Pasal 43 bahwa rumusan Pasal 39 dan Pasal 39A berlaku juga bagi wakil, kuasa, pegawai dari wajib pajak, atau dari pihak lain yang menyuruh melakukan, yang turut serta melakukan, yang menganjurkan, atau yang membantu melakukan delik sudah menunjukkan adanya penerapan konsep vicarious liability ini. Hal tersebut sama sekali tidak diindikasikan dalam UU KUP. Namun demikian, konsisten dengan pengertian vicarious liability yaitu bahwa unsur perbuatan (delik) yang dilakukan oleh terdakwa ini diabaikan dalam arti tidak diperlukan, maka seharusnya Pasal 43 itu tidak menggunakan konsep ini karena dalam KUHP pun dikenal rumusan menyuruh melakukan, yang turut serta melakukan, yang menganjurkan, atau yang membantu melakukan delik. Dengan kata lain, dengan menyuruh lakukan, menganjurkan, atau pun membantu melakukan delik dalam konteks KUHP dapat disebut sebagai perbuatan pidana. Padanan ketentuan ini adalah Pasal 55 ayat 1 dan 56 KUHP yang mengatur bahwa mereka yang melakukan, menganjurkan, menyuruh melakukan, dan turut serta dipidana sebagai pelaku tindak pidana, sedangkan mereka yang dengan sengaja memberi bantuan dan atau kesempatan, dipandang sebagai pembantu kejahatan. Dengan demikian, unsur tindak pidana ini tetap ada atau relevan dalam konteks Pasal 43 ini.

\section{Masalah Sanksi Pidana terhadap Wajib Pajak Badan dalam Konteks UU KUP}

Apabila memang rumusan delik-delik di dalam UU KUP ini menggunakan konsep Tiada Pidana Tanpa Kesalahan, jelas sekali bahwa UU KUP ini tidak mengenal pidana terhadap korporasi. Hal ini memang cukup ironis, mengingat rumusan delik yang digunakan semestinya dapat diinterpretasikan sebagai korporasi sekalipun istilah yang digunakan adalah "setiap orang" seperti yang telah dipaparkan sebelumnya. Simpulan ini seharusnya dapat didukung dengan beberapa hal berikut:

Pertama, Teori unsur kesalahan (kesengajaan dan kelalaian) ini dapat melekat pada sikap mental atau mens rea pelaku delik. Karena korporasi ini tidak berwujud, maka jelas sekali bahwa kedua unsur ini tidak mungkin dapat ditemukan dalam konteks wajib pajak badan atau korporasi.

Kedua, Dalam praktik, pelaku delik di bidang perpajakan ini adalah individu dan tampaknya inilah yang melatarbelakangi penggunaan istilah setiap orang dalam rumusan delik Pasal 38, 39, dan 39A, terlepas dari adanya kemungkinan bahwa individu ini bertindak untuk dan atas nama korporasi. Dalam aspek ini, cukup logis apabila makna istilah setiap orang dalam rumusan delik dapat diartikan untuk meliputi juga wajib pajak badan atau korporasi. Sekalipun demikian, jelas sekali bahwa pertanggungjawaban pidana korporasi ini sama sekali tidak mendapat tekanan dalam UU KUP ini.

Ketiga, Rumusan sanksi yang digunakan dalam Pasal 39 dan 39A ini adalah pidana tambahan (bukan pidana subsider) yang diindikasikan dengan kata sambung dan dan disertai. Pidana tambahan ini secara tata bahasa memiliki makna bahwa pelaku delik (yaitu individu) itu dapat di pidana dengan denda dan penjara. Rumusan sanksi ini tampaknya tidak dapat diartikan bahwa pidana kurungan itu dapat dikenakan terhadap si individu pelaku, sedangkan sanksi denda dikenakan terhadap korporasi sebagai wajib pajak badan. Dengan demikian, secara harfiah, sanksi pidana baik denda maupun kurungan ini dapat ditafsirkan hanya dikenakan terhadap individu sebagai pelaku delik. Memang hal ini tidak dapat secara otomatis diartikan bahwa individu itu sebagai satusatunya pihak yang bertanggungjawab karena definisi penanggung pajak dalam Pasal 1 angka 28 UU KUP ini adalah orang pribadi atau badan yang bertanggung jawab atas pembayaran pajak, termasuk wakil yang menjalankan hak dan memenuhi kewajiban wajib pajak sesuai dengan ketentuan peraturan perundangundangan perpajakan. Dengan demikian, jelas sekali bahwa apabila delik yang dilakukan ini terkait dengan pemenuhan kewajiban wajib pajak badan, wajib pajak yang bersangkutan dapat menjadi pihak yang wajib menanggung pembayaran pajak sekalipun pajak ini diakibatkan oleh pihak lain yang melakukan delik itu. 
Adapun pertanyaan terakhir yang perlu diajukan sehubungan dengan rumusan sanksi sesuai dengan UU KUP ini adalah efektifitasnya dalam mencegah terjadinya delik dan/atau mengembalikan keadaan (yang tidak seimbang setelah terjadinya delik) seperti sediakala. Hal ini cukup beralasan mengingat sanksi pidana yang di atur dalam UU KUP hanyalah berupa sanksi-sanksi formal. Padahal, dalam beberapa aspek, khususnya untuk mencapai suatu tujuan pemidanaan terhadap korporasi, sanksi informal atau negative yang berupa legal sanction, occumpational sanctions, dan social sanction dapat dipertimbangkan (Muladi dan Priyatno, 2010:238). Sejalan dengan ide ini, sanksi berupa pengumuman di media masa tentang korporasi yang melakukan suatu delik pajak tertentu atau social sanction atau penempatan korporasi itu dalam suatu badan pengawas sementara atau legal sanction, atau bahkan pelepasan jabatan bagi pengurus yang bertanggungjawab atau occumpational sanction layak untuk dipertimbangkan.

\section{PENUTUP \\ Kesimpulan}

Dengan demikian jelas sekali bahwa rumusan delik dalam UU KUP ini tidak selaras dengan teoriteori pertanggungjawaban pidana dalam konteks hukum pidana, sekalipun pada Pasal 38, 39, 39A, dan 43 ditujukan untuk mengatur ketentuan pidana dalam bidang perpajakan. Pada intinya, sekalipun konteks rumusan delik Pasal 38, 39, 39A seakan-akan mencakup pula Wajib Pajak Badan atau korporasi sebagai pelaku delik, namun hal ini tidak konsisten karena rumusan sanksi pidana dalam pasal-pasal ini dapat diinterpretasikan tidak mengakomodasi korporasi sebagai pelaku delik atau dader. Selain itu, ketidakkonsistenan ini juga tampak dalam teori pertanggungjawaban pidana yang secara implisit disebutkan dalam rumusan delik. Apabila memang rumusan delik bermaksud untuk dapat mencakup pula korporasi sebagai pelaku delik yang seharusnya juga dapat di pidana, maka konsep pertanggungjawaban pidana yang dapat diterapkan adalah strict liability dan/atau vicarious liability dan bukan konsep klasik yaitu tiada pidana tanpa kesalahan.

Rumusan delik yang menggunakan istilah-istilah kealpaan atau kesengajaan jelas-jelas menunjukkan penerapan konsep tradisional tidak ada pidana tanpa kesalahan, sementara itu di lain pihak, unsur kelalaian dan kesengajaan itu secara teoritis tidak akan pernah tampak dalam wajib pajak badan atau korporasi. Hal tersebut semestinya sejalan dengan pandangan umum,bahwa suatu korporasi atau wajib pajak badan adalah subjek hukum yang sifatnya nonbadaniah. Dengan demikian, implikasi dari pengaturan khusus untuk wajib pajak badan sebagai subjek hukum ini adalah adanya formulasi mengenai dalam hal mana atau kapan suatu delik pidana di bidang perpajakan dikatakan telah dilakukan oleh korporasi (Amrullah, 2011:10).

Aspek kedua yang perlu diperhatikan lebih lanjut dalam ketentuan pidana sebagaimana diatur dalam UU KUP ini adalah apakah rumusan delik ini juga dimaksudkan untuk dapat mencakup para manajemen puncak yang tercermin dalam suatu konsep vicarious liability. Dengan demikian, apabila memang UU KUP bermaksud menggunakan konsep strict liability ataupun vicarious liability dalam Bab VIII Ketentuan Pidana, ini diakomodasi dengan beberapa hal yaitu: 1. Reformulasi pola aturan pemidanaan korporasi yang mencakup pengaturan kapan suatu korporasi melakukan tindak pidana dan kapan korporasi itu dapat dipertanggungjawabkan; 2. Penghilangan unsur kesengajaan atau kealphaan dalam rumusan delik; 3 . Pengaturan sanksi pidana yang terpisah untuk wajib pajak badan atau korporasi, yangmana sanksi pidana yang dapat diterapkan adalah pidana denda (sebagai pidana pokok), atau pun pidana tambahahan misalnya pencabutan hak-hak tertentu atau perampasan barangbarang tertentu. Sebagai pembanding misalnya, adalah sanksi pidana tambahan bagi korporasi yang di atur dalam UU No. 8 Tahun 2010 tentang Pencegahan dan Pemberantasan Tindak Pidana Pencucian Uang, yang mencakup pencabutan izin usaha dan pelarangan dan pembubaran korporasi; 4. Pengaturan dalam rumusan delik bahwa korporasi dan/atau manajemen puncak dalam wajib pajak badan dapat dianggap sebagai pelaku delik yang harus bertanggungjawab atas tindak pidana yang dilakukan oleh karyawannya. Pengaturan ini seharusnya lebih konsisten dengan istilah Penanggung Pajak dalam Pasal 1 angka 28 UU KUP, sekalipun penanggung pajak disini tidak selalu sama dengan penanggungjawab pidana. Penanggung pajak dapat berhubungan dengan mereka yang harus bertanggungjawab untuk pemenuhan pembayaran pajak atau kewajiban pajak secara umum, sementara penanggungjawab tindak pidana adalah mereka yang dianggap dapat dipidana karena adanya suatu delik pidana; dan 5. Pengaturan mengenai sanksi pidana yang akan dikenakan terhadap pelaku delik juga harus diformulasikan kembali sehingga dapat mencakup pidana formal seperti kurungan dan denda dan pidana informal atau negatif seperti occumpational sanction, legal sanction, dan social sanction. Selain itu pula, pembentuk undang-undang harus mempertimbangkan 
pengenaan sanksi yang berbeda bagi korporasi dan perorangan atau individu. Tolok ukur dari sanksi pidana ini pada akhirnya adalah efektivitas sanksi pidana untuk mencegah terjadinya suatu delik (hal ini mengacu pada teori pencegahan dalam konteks hukum penitensier) atau pun untuk mengembalikan keadaan seperti sediakala atau restitutio in integrum.

\section{Rekomendasi}

Terlepas dari penggunaan konsep ini, maka yang mungkin harus dikaji lebih lanjut adalah apakah delik pajak ini merupakan kejahatan yang luar biasa sifatnya yang merupakan prasyarat secara teori untuk penggunaan konsep strict liability atau vicarious liability. Dengan banyaknya kasus pidana yang terkait dengan delik pajak, sudah saatnya pembuat undangundang mempertimbangkan kembali untuk mengatur secara spesifik delik pajak ini dalam suatu aturan khusus sebagai delik luar biasa. Hal ini tentu saja berimplikasi pada konsep pertanggungjawaban pidana yang digunakan dalam UU KUP.

\section{DAFTAR PUSTAKA}

Adhyaksana, M. Yusfidli, 2008, Pertanggungjawaban Pidana Korporasi dalam Penyelesaian Kasus Bantuan Likuiditas Bank Indonesia (BLBI), Tesis Program Magister Ilmu Hukum, Semarang: Universitas Diponegoro.
Amrullah, M. Arief, 2011, Kebijakan Formulasi Pidana dan Pemidanaan Korporasi dalam Undang-Undang tentang Pencegahan dan Pemberantasan Tindak Pidana Pencucian Uang, Makalah dalam Seminar Nasional Dies Natalis XXX Universitas Wijaya Kusuma Surabaya.

Arief, Barda Nawawi, 2010, Bunga Rampai Kebijakan Hukum Pidana, Jakarta: Kencana Prenada Media Group, Jakarta.

Farid, H. A. Zainal Abidin, 2007, Hukum Pidana I, Jakarta: Sinar Grafika.

Kitab Undang-Undang Hukum Pidana (KUHP), Bandung: Citra Umbara.

La Fave, Wayne R. and Austin W. Scott, 1986, Criminal Law, second edition, West Publishing Company.

Mertokusumo, Sudikno, 2007, Mengenal Hukum: Suatu Pengantar, edisi kelima, Yogyakarta: Liberty.

Moeljatno, 2008, Asas-asas Hukum Pidana, Jakarta: Rineka Cipta.

Muladi dan Dwidja Priyatno, 2010, Pertanggungjawaban Pidana Korporasi, Jakarta: Kencana Prenada Media Group.

Saidi, Muhammad Djafar dan Eka Merdekawati Djafar, 2011, Kejahatan di Bidang Perpajakan, Jakarta: Rajawali Pers.

Undang-Undang No. 6 Tahun 1983 sebagaimana telah diubah terakhir dengan Undang-Undang No. 16 Tahun 2009 tentang Ketentuan Umum dan Tata Cara Perpajakan. 